- FINANSE I PRAWO FINANSOWE.

- Journal of Finance and Financial Law $•$

Czerwiec/June 2018 • vol. 2(18): 37-49

https://doi.org/10.18778/2391-6478.2.18.04

\title{
ZNAJOMOŚĆ PRAW I OBOWIAZZKÓW - JAKO JEDNA Z METOD OCHRONY KONSUMENTA NA RYNKU USŁUG BANKOWYCH
}

\author{
Magdalena Lubaś \\ Wydział Prawa i Administracji \\ Uniwersytet Marii Curie-Skłodowskiej w Lublinie
}

\section{Streszczenie}

Celem niniejszego artykułu jest wskazanie praw i obowiązków, jakie przysługują konsumentowi na rynku usług bankowych, czego może się domagać od banku, a na co nie musi się zgadzać. Jeśli konsument wie, jakie uprawnienia są mu zagwarantowane z mocy obowiązującego prawa, może tę wiedzę wykorzystać w kontakcie z bankiem. Jednak rzadko kto wie, co jest zawarte w ustawach czy rozporządzeniach, ponieważ nie każdy zna prawo. Łacińska premia wywodząca się z prawa rzymskiego Ignorantia iuris nocet (nieznajomość prawa szkodzi), dobitnie odzwierciedla położenie konsumentów zarówno na ryku usług bankowych, jak i w całym obrocie gospodarczym. Tezą, która będzie dowodzona w niniejszym artykule, jest to, że znajomość praw i obowiązków może stanowić jeden ze skutecznych mechanizmów obronnych konsumenta na rynku usług bankowych? Artykuł oparty jest na badaniach przeprowadzonych na temat znajomości praw klienta na rynku usług bankowych.

Słowa kluczowe: Bankowy Fundusz Gwarancyjny, bank, rachunek bankowy, kredyt, usługi bankowe.

JEL Class: G21. 


\section{WPROWADZENIE}

Obecnie prawie każda osoba mająca pełną zdolność do czynności prawnych jest posiadaczem rachunku bankowego. $Z$ tego tytułu ma wiele udogodnień, np. możliwość rozliczeń bezgotówkowych, otrzymywanie pensji czy innych świadczeń na swój rachunek. Aby można było mówić o rachunku osobistym, należy zacząć od jego założenia. Powstaje on poprzez zawarcie umowy pomiędzy potencjalnym posiadaczem a bankiem. Art. 725 kodeksu cywilnego stanowi, czym jest przywołana umowa rachunku bankowego. W umowie muszą być zawarte wszelkie istotne kwestie dotyczące rachunku. Jednak ilość stron umowy często odstrasza od czytania. Osoba zakładająca rachunek bankowy po „szybkim” prześledzeniu umowy podpisuje ją niezwłocznie, nie wczytując się dogłębnie $\mathrm{w}$ jej postanowienia. W umowie są zawarte wszelkie istotne kwestie. Jednak ludzie często nie zdają sobie sprawy, jakie prawa przysługują im w zetknięciu $\mathrm{z}$ bankiem. Często godzą się na to, co im się powie, bez szukania alternatywnych rozwiązań. Usługi bankowe to nie tylko umowy o rachunku bankowym, to także udzielanie kredytów, wydawanie instrumentów pieniądza elektronicznego i wiele innych. Wiele kwestii na temat funkcjonowania banków oraz uprawnień odnoszących się do konkretnej sytuacji konsument może znaleźć w ustawie z dnia 29 sierpnia 1997 r. - Prawo bankowe [Dz.U. 1997, nr 140, poz. 939]. W dalszej części artykułu zostaną przedstawione badania na temat znajomości praw i obowiązków konsumentów na rynku usług bankowych. W badaniu wzięły udział 143 osoby. Narzędziem służącym do przeprowadzenia badania był kwestionariusz, składający się z 10 pytań merytorycznych odnoszących się do rynku bankowego i jedenastego polegającego na ocenie swojej wiedzy. Kwestionariusz został przesłany badanym drogę internetową. Po przesłaniu kwestionariusza osoby wypełniające mogły zweryfikować poprawność udzielonych dopowiedzi. Kwestionariusz zawierał odpowiedzi jednokrotnego wyboru. W badaniu wzięły udział osoby w różnych grupach wiekowych i o różnym poziomie wykształcenia. $\mathrm{W}$ artykule analizowana będzie liczba poprawnych i błędnych odpowiedzi udzielonych na zadane pytania. Pracę zakończą wnioski podsumowujące badanie.

\section{KONSUMENT - ZNACZENIE NADANE PRZEZ USTAWODAWCE}

W polskim ustawodawstwie obecna jest następująca definicja pojęcia konsumenta: „za konsumenta uważa się osobę fizyczną dokonującą z przedsiębiorcą czynności prawnej niewiązanej bezpośrednio z jej działalnością gospodarczą luba zawodową" [art. 22, Ustawa z dnia 23 kwietnia 1964 r..., Dz.U. 1964, nr 16, poz. 93]. „Konsumentem nie może być osoba prawna czy jednostka organizacyjna mająca zdolność prawną, nawet gdyby dokonywała czynności prawnej 
niewiązanej bezpośrednio z jej działalnością gospodarczą lub zawodową" [Sokołowski i Kidyba 2012: 60 i n.]. Jak wynika z ustawodawstwa, konsumentem można być w sferze działalności gospodarczej, jak i zawodowej. „Cechą przyjętych rozwiązań jest istnienie stosunku bezpośredniości czynności związanych $\mathrm{z}$ prowadzeniem działalności gospodarczej lub zawodowej. Bezpośredniość wiązać się musi z czynnościami skierowanymi na prowadzenie działalności zarobkowej, a więc takiej, w której występuje efekt zysku" [Kidyba 2017: 39]. Do pojęcia konsument odnosi się szereg praw. Powszechnie uznaje się konsumenta za stronę słabszą na rynku, która nie posiada tyle wiedzy jak przedsiębiorstwa oraz często nie umie sama skutecznie się obronić. Przedsiębiorcy bardzo często mogą wykorzystywać nieznajomość prawa przez konsumentów poprzez stosowanie nieuczciwych praktyk, które w konsekwencji prowadzą do podejmowania przez konsumentów niekorzystnych dla siebie działań, a wręcz sprzecznych ze swoim własnym interesem. W związku z powyższymi argumentami, wiele państw stosuje mechanizmy ochrony praw strony słabszej. W Rzeczpospolitej Polskiej, ochrona praw konsumenta ma swoje unormowanie konstytucyjne. „Władze publiczne chronią konsumentów, użytkowników i najemców przed działaniami zagrażającymi ich zdrowiu, prywatności i bezpieczeństwu oraz przed nieuczciwymi praktykami rynkowymi. Zakres tej ochrony określa ustawa" [art. 76, Konstytucja Rzeczypospolitej Polskiej z dnia 2 kwietnia 1997 r., Dz.U. 1997, nr 78, poz. 483]. Do praw konsumenta odnosi się również szereg innych ustaw, rozporządzeń, m.in. ustawa z dnia 16 lutego 2007 r. o ochronie konkurencji i konsumentów, ustawa z dnia 30 maja 2014 r. o prawach konsumenta. Po wstąpieniu Polski do Unii Europejskiej prawa konsumenta są także chronione normami dyrektyw Komisji Europejskiej, które zostały podsumowane w broszurze pt. Dziesięć podstawowych zasad wydanej przez tę instytucję w 2007 r. W Polsce nad przestrzeganiem praw konsumenta czuwa Prezes Urzędu Ochrony Konkurencji i Konsumentów (UKOiK). Do jego głównych zadań należy ochrona zbiorowych interesów konsumentów poprzez przeciwdziałanie nieuczciwym praktykom rynkowym oraz zwalczanie niedozwolonych postanowień umownych. Ochrona praw konsumenta odbywa się również na szczeblach powiatów. Powołani są do tego celu powiatowi rzecznicy praw konsumentów, którzy świadczą pomoc przy indywidualnych sprawach konsumentów. W Polsce działa również duża liczba organizacji pozarządowych, których celem jest ochrona interesów konsumenta m.in.: Federacja konsumentów, Stowarzyszenie Konsumentów Polskich. 


\section{RYNEK USŁUG BANKOWYCH}

„Bank jest osobą prawną utworzoną zgodnie z przepisami ustaw, działającą na podstawie zezwoleń uprawniających do wykonywania czynności bankowych obciążających ryzykiem środki powierzone pod jakimkolwiek tytułem zwrotnym" [art. 2, Ustawa z dnia 29 sierpnia 1997 r..., Dz.U. 2017.0.1876 t.j]. Pojęcie bank wywodzi się francuskiego słowa banque, co oznacza ławę. Bank może wykonywać tylko określone w ustawie czynności. „Banki to instytucje, których głównym przedmiotem działalności są usługi o charakterze depozytowo-kredytowym, za pośrednictwem których dokonuje się alokacja środków finansowych w gospodarce" [Rutkowska-Tomaszewska 2013: 47].

Bank dokonuje licznych operacji, które można podzielić na: finansowe, depozytowe, usługi obrotu a także doradczo-konsultingowe. Na czele banków stoi Narodowy Bank Polski. „Podstawowym celem działalności NBP jest utrzymanie stabilnego poziomu cen, przy jednoczesnym wsparciu polityki gospodarczej Rządu, o ile to nie ogranicza podstawowego celu NBP" [art. 3 ustawy z dnia 29 sierpnia 1997 r. ..., Dz.U. 1997, nr 140, poz. 938]. „Bank centralny należy do publicznego systemu finansowego, chociaż jego działalność w swej zasadniczej części jest ściśle związana $\mathrm{z}$ funkcjonowaniem rynkowego systemu finansowego" [Pietrzak i in. 2008: 61]. System bankowy w Polsce w obecnym kształcie odpowiada rozwiązaniom występującym w krajach o rozwiniętych systemach finansowych. Jest on efektem przemian, które dokonywały się w latach 90 . „W gospodarce rynkowej klasycznym modelem systemu bankowego jest tzw. dwuszczeblowy system bankowy. Składa się on z banku centralnego oraz różnego typu banków funkcjonujących na poszczególnych rynkach finansowych. System bankowy stanowi część systemu finansowego" [www1].

\section{BADANIA NA TEMAT ZNAJOMOŚCI PRAW I OBOWIĄZKÓW KONSUMENTÓW NA RYNKU UStUG BANKOWYCH}

Pierwszym zadanym w kwestionariuszu pytaniem było: Bank musi czy może uzasadnić odmowę udzielenia kredytu? Do wyboru było 3 warianty odpowiedzi: 1. - musi; 2. - może; 3 . - nie wiem. $Z$ całokształtu ustawodawstwa nie wyłania się obowiązek ciążący na banku co do uzasadniania odmowy udzielenia kredytu. $51 \%$ badanych błędnie opowiedziało za odpowiedzią, że na banku ciąży obowiązek uzasadnienia swojej decyzji. 44,1\% osób uczestniczących w badaniu wskazało poprawną odpowiedź, że bank może uzasadniać decyzję o odmowie udzielenia kredytu. $4,9 \%$ badanych wskazało, że nie zna odpowiedzi na to pytanie. 


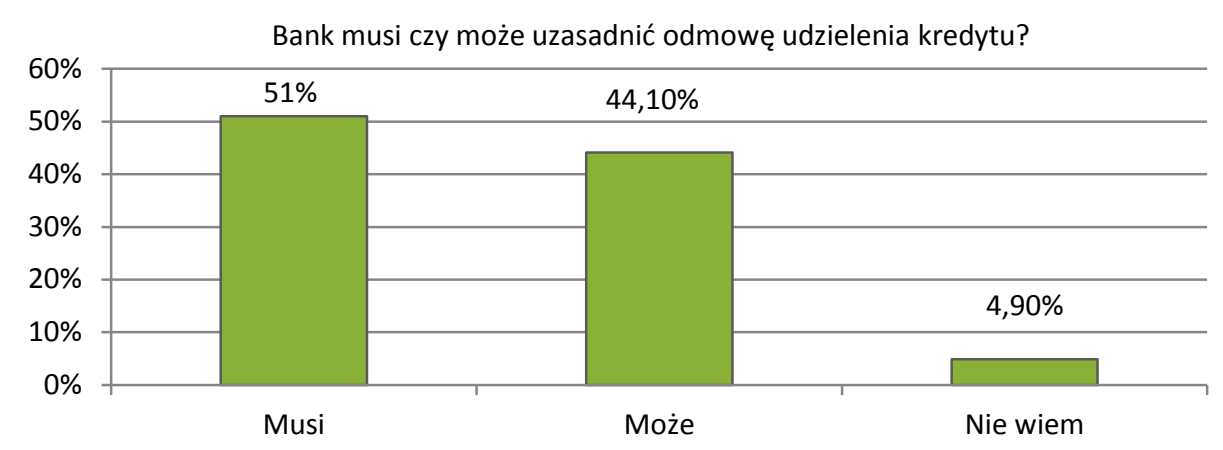

Źródło: opracowanie własne.

Czy bank ma prawo naliczać opłatę od wypłaty środków z kasy banku gdzie mamy rachunek bankowy?

Pierwszym wariantem odpowiedzi w tym pytaniu było, że tak, bank ma prawo, drugi wariant a contrario, że bank nie na prawa, trzeci nie znam odpowiedzi na to pytanie. $\mathrm{Z}$ żadnych przepisów prawa nie wynika, że bank ma takie prawo. $46,1 \%$ badanych błędnie wskazało że bank ma prawo do naliczania opłat od wypłaty środków. Poprawnie odpowiedziało 39,9 \% osób. 14\% badanych wskazało, że nie zna odpowiedzi na zadane pytanie.

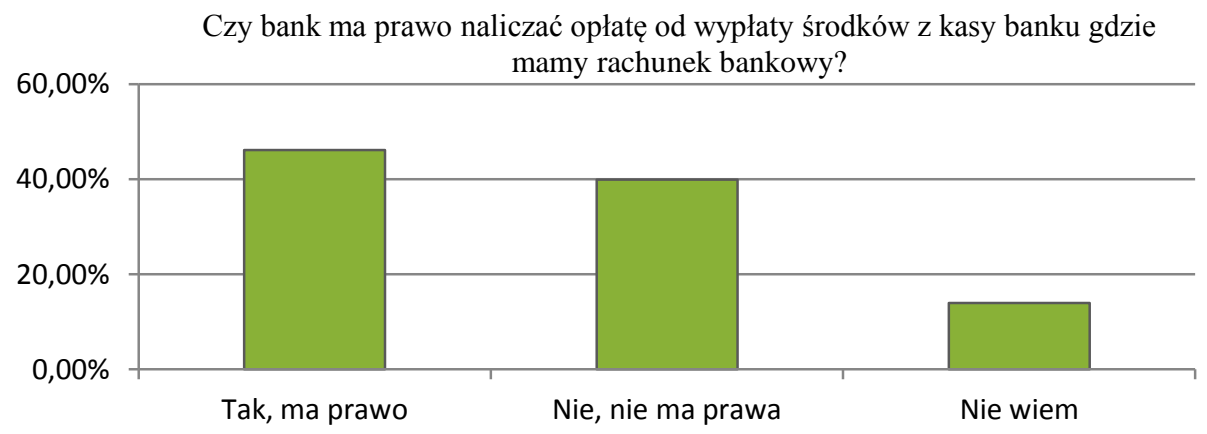

Źródło: opracowanie własne.

Czy bank ma prawo pobierać opłatę za wpłatę środków na konto w banku gdzie mamy rachunek bankowy?

Analogicznie jak w poprzednim pytaniu osoby biorące udział w badaniu do wyboru miały takie same warianty odpowiedzi. W tym przypadku $\mathrm{z}$ ustawodawstwa nie wyłania się prawo pobierania opłat za wypłatę środków z konta w banku, który prowadzi rachunek bankowy. Poprawną odpowiedź udzieliło 49\% 
badanych. 29,8\% osób błędnie wskazało, że bank dysponuje prawem pobierania opłat. $21,2 \%$ badanych wskazało, że nie zna odpowiedzi. Osoby biorące udział $\mathrm{w}$ badaniu poradziły sobie lepiej $\mathrm{z}$ odpowiedzią na to pytanie niż $\mathrm{z}$ pytaniem poprzedzającym. Różnica poprawnych odpowiedzi w zestawieniu obydwu pytań wynosi $10 \%$.

Czy bank ma prawo pobierać opłatę za wpłatę środków na konto w banku

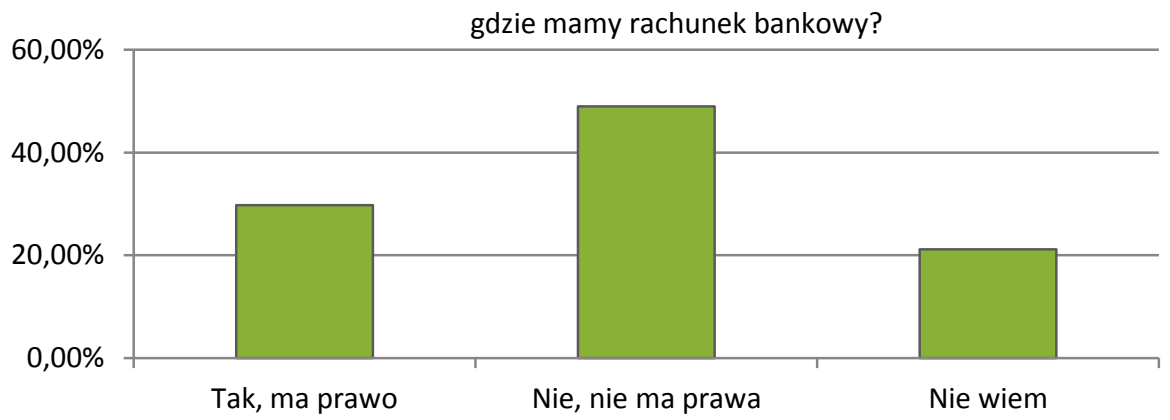

Źródło: opracowanie własne.

Czy osoba ubiegająca się o kredyt w banku XYZ, musi mieć konto w tym banku?

$16,4 \%$ badanych jest błędnie przekonanych, że aby otrzymać pozytywną decyzję o przyznaniu kredytu trzeba być posiadaczem rachunku bankowego w banku potencjalnego kredytodawcy. Uwarunkowanie decyzji o przyznaniu kredytu od korzystania z innego produktu oferowanego przez bank jest niezgodne z prawem. Potwierdza to wyrok Sądu Ochrony Konkurencji i Konsumentów z dnia 30 stycznia 2006 r. Poprawnej odpowiedzi udzieliła większość ankietowanych $-67,9 \%$. Odpowiedzi na to pytanie nie znało $15,7 \%$ badanych.

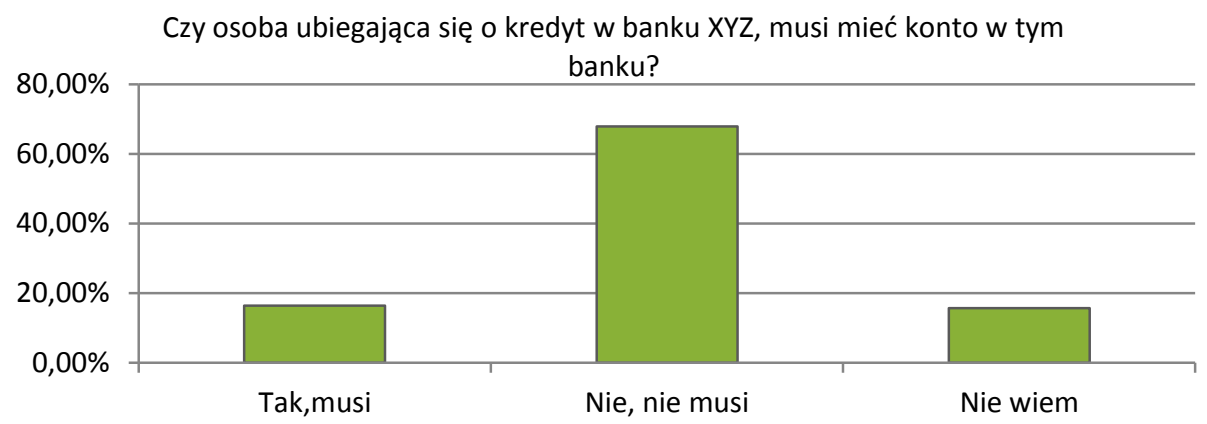

Źródło: opracowanie własne. 


\section{Do jakiej kwoty środki na rachunku bankowym gwarantowane są przez Bankowy Fundusz Gwarancyjny?}

Badani mieli do wyboru 4 warianty odpowiedzi. Pierwszy z nich zawierał kwotę 50 tysięcy euro, drugi wariant 100 tysięcy euro, trzeci 1 milion euro, czwarty zaś to odpowiedź - nie wiem. Art. 24 ustawy z dnia 10 czerwca 2016 r. o Bankowym Funduszu Gwarancyjnym, systemie gwarantowania depozytów oraz przymusowej restrukturyzacji - wskazuje, że BFG gwarantuje środki na rachunku do 100 tysięcy euro. Istnienie systemu gwarantowania depozytów w systemie bakowym ,umożliwia działanie o charakterze interwencyjnym w warunkach kryzysu bankowego" [Iwanicz-Drozdowska 2000: 194]. Poprawnej odpowiedzi udzieliło 40,8\% badanych. Na kwotę 50 tysięcy euro postawiło $26,1 \%$ osób, zaś za kwotą 1 miliona euro opowiedziało się 13,4\% badanych. $19,7 \%$ ankietowanych wybrało odpowiedź - nie wiem.

Do jakiej kwoty środki na rachunku bankowym, gwarantowane są przez Bankowy Fundusz Gwarancyjny?

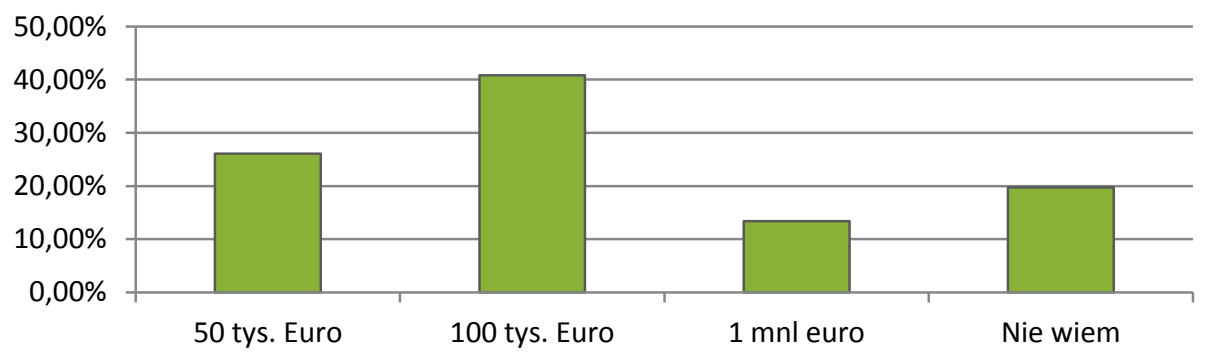

Źródło: opracowanie własne.

Czy można odstąpić (a jeśli tak to w jakim terminie) od umowy o usługi bankowe zawartej na odleglość?

Art. 27 ustawy z dnia 30 maja 2014 r. o prawach konsumenta [Dz.U. 2014, poz. 827] wyraźnie wskazuje, że od umowy zawartej na odległość (poza lokalem przedsiębiorstwa) można odstąpić w terminie 14 dni od jej zawarcia. Art. 28 tej samej ustawy wskazuje sposób liczenia biegu terminu. W przypadku tego rodzaju umów przysługuje prawo do namysłu. Konsument może odstąpić od niej bez wskazania powodów. Może tego dokonać przez złożenie stosownego oświadczenia $\mathrm{w}$ formie pisemnej z zachowaniem terminów na odstąpienie od umowy. „Ochrona ta wynika $z$ charakteru tych umów i sposobu ich zawierania, charakteryzujących się wykorzystywaniem określonych technik sprzedażowych, zwykle natarczywych lub agresywnych, w celu doprowadzenia do podjęcia przez konsumenta decyzji gospodarczej" [Rutkowska-Tomaszewska 2013: 637]. W tym 
pytaniu badani mieli cztery warianty odpowiedzi. 1. - tak, w ciągu 14 dni od zawarcia umowy; 2. - tak, w ciągu 7 dni od zawarcia umowy; 3. - nie można odstąpić od takiej umowy; 4. - nie wiem. Prawidłowej odpowiedzi udzieliło $52,8 \%$ badanych. Za drugi wariantem odpowiedzi opowiedziało się $24,6 \%$ osób, za trzecim 15,4\%. 7,2\% wskazało, że nie zna odpowiedzi na to pytanie. Ponadto w ustawie o kredycie konsumenckim z 12 maja 2011 r. w art. 15 znajdujemy przepis, który jasno wskazuje obowiązki kredytodawcy co do umowy o kredyt zawieranej na odległość: „W przypadku umowy o kredyt konsumencki zawieranej na wniosek konsumenta na odległość, jeżeli środek porozumiewania się na odległość nie pozwala na przekazanie danych zgodnie z art.13 ust.1 i 2, kredytodawca lub pośrednik kredytowy przekazuje konsumentowi te dane niezwłocznie po zawarciu umowy o kredyt konsumencki na formularzu informacyjnym dotyczącym kredytu konsumenckiego".

Czy można odstąpić (a jeśli tak to w jakim terminie) od umowy o usługi bankowe zawartej na odległość?

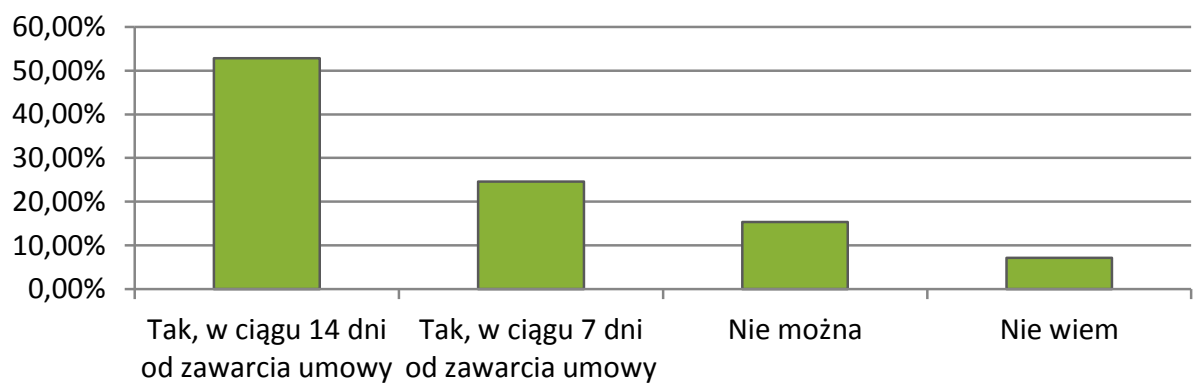

Źródło: opracowanie własne.

Kto odpowiada za dokonane transakcje kartą po jej zastrzeżeniu przez posiadacza?

Po zastrzeżeniu karty przez posiadacza za dokonane transakcje przejmuje odpowiedzialność bank, ma tu umocowanie w art. 28 ust. 5 ustawy z dnia 12 września 2002 r. o elektronicznych instrumentach płatniczych [Dz.U. 2002, nr 169, poz. 1385]. W tym pytaniu badani mieli do wyboru 4 warianty odpowiedzi. 1. - odpowiedzialność ponosi właściciel karty; 2. - bank; 3. - Skarb Państwa; 4. - nie wiem. Najwięcej osób $64,8 \%$ wskazało prawidłową odpowiedź, że odpowiedzialność ponosi bank. 16,2\% wskazało na właściciela karty, 14,1\% badanych że Skarb Państwa. 4,9\% ankietowanych wskazało, że nie zna odpowiedzi na pytanie. 
Kto odpowiada za dokonane transakcje kartą po jej zastrzeżeniu przez

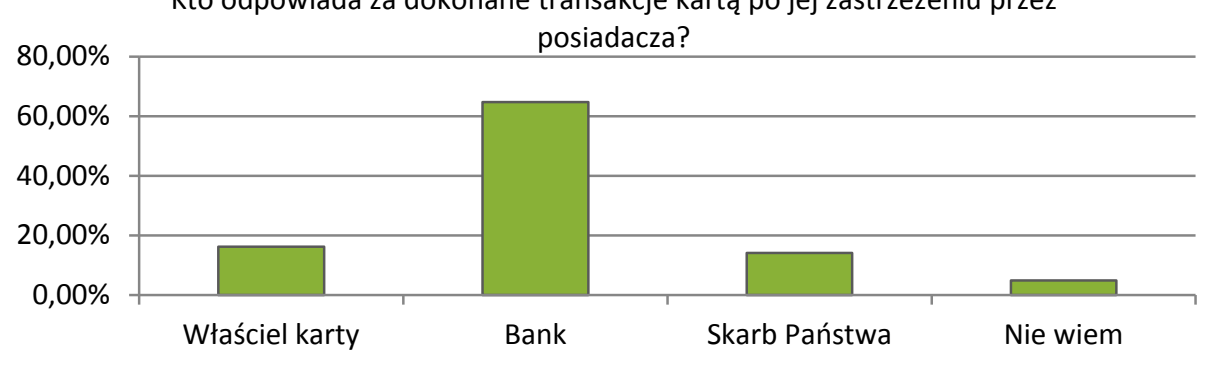

Źródło: opracowanie własne.

Kiedy klient obciążony jest kosztami użycia jego karty przez inną osobę?

$\mathrm{W}$ art. 16 ustawy z dnia 12 września 2002 r. o elektronicznych instrumentach płatniczych [Dz.U. 2002, nr 169, poz. 1385] wymienione są obowiązki ciążące na posiadaczu karty płatniczej. Art. 28 tej samej ustawy wskazuje, że w razie niedopełnienia obowiązków wymienionych w art. 16 koszty użycia karty przez inną osobę ponosi właściciel. Do obowiązków tych zaliczamy np.: przechowywanie karty płatniczej i ochrona kodu identyfikacyjnego, z zachowaniem należytej staranności. 43,7\% osób poprawnie udzieliło odpowiedzi, że klient obciążony jest kosztami, gdy zaniedba swoje obowiązki, np. zaniedba PIN. $38 \%$ wskazało, że klient zawsze obciążony jest kosztami użycia jego karty, $16,2 \%$ wskazało, że nigdy klient nie ponosi odpowiedzialności. 2,1\% badanych wskazało, że nie zna odpowiedzi na pytanie.

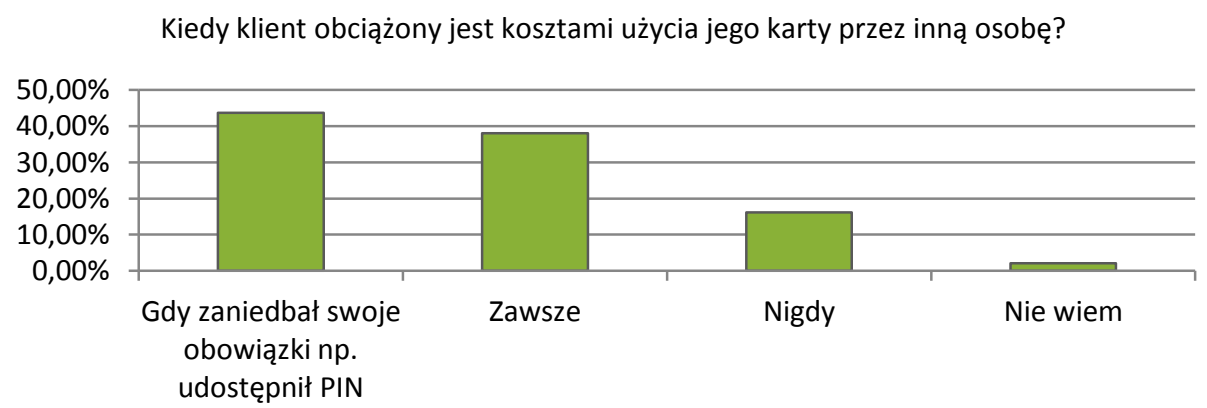

Źródło: opracowanie własne.

Do jakiej kwoty transakcji wykonanych przez osobę trzecią na skutek np. kradzieży konsument odpowiada przed zastrzeżeniem karty?

Według art. 28 ustawy z dnia 12 września 2002 r. o elektronicznych instrumentach płatniczych [Dz.U. 2002, nr 169, poz. 1385] „O ile umowa nie przewi- 
duje inaczej, posiadacza obciążają operacje dokonane zużyciem utraconej karty płatniczej do czasu zgłoszenia wydawcy jej utraty, do kwoty stanowiącej równowartość w złotych 150 euro". Badani mieli do wyboru 4 warianty odpowiedzi. 1. - 150 euro; 2. - 10 tysięcy euro; 3. - całość kwoty; 4. - nie wiem. Najwięcej osób opowiedziało się za wariantem numer 3 , że posiadacz karty odpowiada za całą kwotę, na jaką opiewają transakcje dokonane kartą przed jej zastrzeżeniem - 47,9\%, co jest na mocy przytoczonej wyżej odpowiedzi błędne. Poprawnej odpowiedzi udzieliło 21,1\%. Za kwotą 10 tysięcy euro opowiedziało się $19 \%$ badanych. Na nieznajomość odpowiedzi na pytanie wskazało 12\% osób.

Do jakiej kwoty transakcji wykonanych przez osobę trzecią na skutek np. kradzieży konsument odpowiada przed zastrzeżeniem karty?

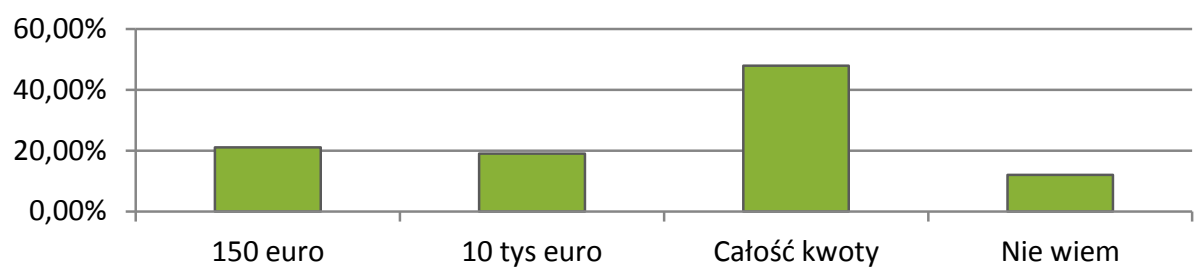

Źródło: opracowanie własne.

\section{Czy w razie zgubienia dowodu osobistego fakt ten powinno się zglosić do banku?}

Samo zgłoszenie zgubienia czy kradzieży na policję to za mało. Fakt ten należy zgłaszać również do banku, po to, by uniemożliwić osobie trzeciej zaciągnięcia kredytu na konto właściciela dowodu osobistego. Badani w pytaniu mieli do dyspozycji 3 warianty odpowiedzi: 1. - tak; 2. - nie; 3. - nie wiem. Prawidłowej odpowiedzi udzieliło 72,3\% badanych. Złej odpowiedzi dokonało 19,2\% osób. $8,5 \%$ badanych wskazało, że nie zna odpowiedzi na pytanie.

Czy w razie zgubienia dowodu osobistego fakt ten powinno się zgłosić do

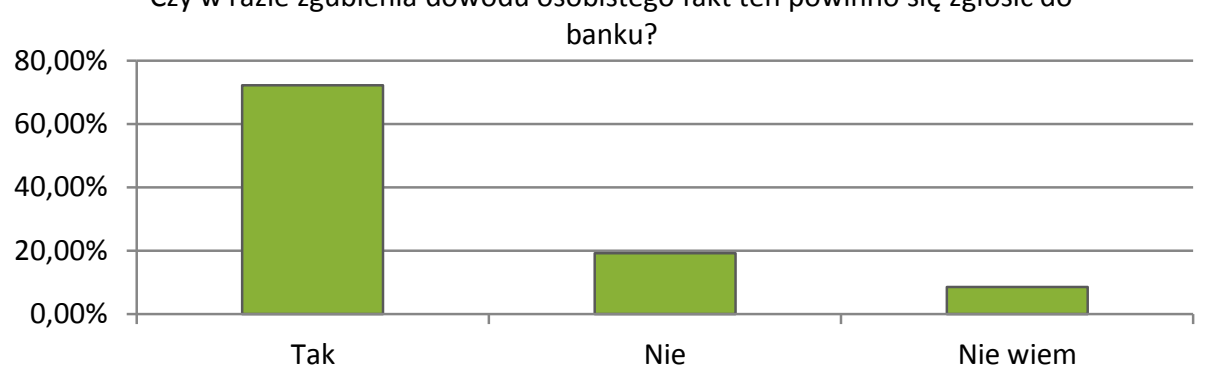

Źródło: opracowanie własne. 


\section{WNIOSKI WYNIKAJĄCE Z PRZEPROWADZONEGO BADANIA}

Poniżej przedstawiony zostaje wykres wskazujący odpowiedź badanych na 11 pytanie. Nie miało ono charakteru merytorycznego. Polegało na subiektywnej ocenie znajomości swojej wiedzy z zakresu praw konsumenta na rynku usług bankowych.

Jak ocenia Pan/Pani swoją wiedzę na temat praw konsumenta na rynku usług bankowych?

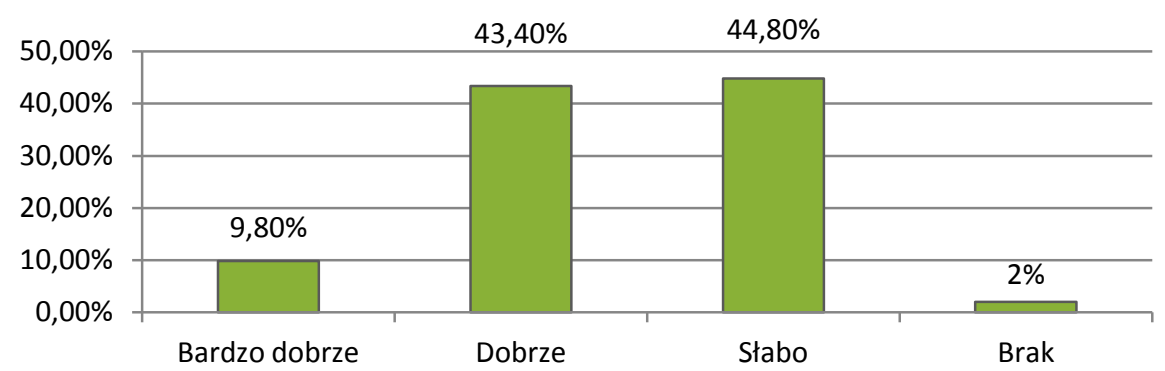

Źródło: opracowanie własne.

Poziom znajomości praw i obowiązków konsumentów na rynku usług finansowych kształtuje się na niskim poziomie.

Najwięcej poprawnych odpowiedzi udzielono na pytanie 10, „Czy w razie zgubienia dowodu osobistego fakt ten powinno się zgłosić do banku”. Wskazuje to na wysoki poziom wiedzy wśród badanych odnośnie środków obronnych na wypadek takiego zajścia. Wskazana sytuacja w pytaniu jest bardzo często występująca w społeczeństwie, co może świadczyć o tak wysokim wyniku poprawnych odpowiedzi.

Najmniej poprawnych odpowiedzi udzielono na pytanie drugie: „Czy bank ma prawo naliczać opłatę od wypłaty środków z kasy banku gdzie mamy rachunek bankowy?". Badani nie maja wiedzy na temat sytuacji najbardziej typowych, stanowiących podstawowy zakres działalności finansowej.

$0,7 \%$ badanych nie udzieliło poprawnie odpowiedzi na żadne pytanie. Jednej poprawnej odpowiedzi udzieliło $4,9 \%$. Dwóch poprawnych odpowiedzi udzieliło $11,19 \%$. Trzy poprawne odpowiedzi uzyskało 20,28\%, cztery $18,88 \%$ pięciu $14.68 \%$. 7\% badanych uzyskało 7 poprawnych odpowiedzi. Osiem popranych odpowiedzi udzieliło $4,19 \%$ badanych. Wynik 9 pozytywnych odpowiedzi otrzymało 2,8\% osób. Maksymalną liczę popranych odpowiedzi miało zaledwie $1,4 \%$ badanych. 
Jak wykazały przeprowadzone badania, znajomość swoich praw i obowiązków na rynku usług bankowych jest znikoma. Społeczeństwo wykazuje niski poziom wiedzy w tej dziedzinie.

Co należy zrobić aby ponieść niski poziom znajomości praw i obowiązków konsumentów na rynku usług bankowych?

Największą trudnością w kontakcie klientów z bankami jest niskim poziom znajomości przez konsumentów swoich praw i obowiązków. Klienci nie wiedzą często o co pytać pracowników banków lub gdzie mogą pozyskać potrzebne informacje. Niezbędny jest proces doinformowywania konsumentów. Powinno to się odbywać w taki sposób, aby informacja dotarła do każdego podmiotu na rynku usług bankowych. Może to przejawiać się za pośrednictwem reklamy społecznej, szkoleń oferowanych przez banki swoim klientom czy cykliczne próby kontaktu ze strony banku z konsumentem w celu zasięgnięcia informacji czy klient ma jakieś ważne pytania do banku. To właśnie banki powinny być propagatorami wiedzy z zakresu znajomości praw i obowiązków konsumentów na rynku bankowym, ponieważ oni uchodzą w tej dziedzinie za ekspertów.

Jednak sama znajomość praw i obowiązków to często za mało, jeżeli pomimo otrzymanej informacji klient nie do końca ją zrozumie lub nie wykorzysta do podjęcia właściwej decyzji w kontakcie $\mathrm{z}$ bankiem. Konsument nabytą wiedzę musi wykorzystać w praktyce. Gdy tego nie zrobi, na nic trudy związane z podnoszeniem wiedzy konsumentów na rynku bankowym. To, czy klient będzie bardziej bezpieczny, zależy tylko od tego, w jaki sposób spożytkuje zdobytą wiedzę.

\section{PODSUMOWANIE}

„Najlepszą obroną jest atak”. Jednak aby zaatakować, należy mieć odpowiednie narzędzie, ,asa w rękawie”. W przypadku konsumenta na rynku usług bankowych ,asem” może być znajomość praw i obowiązków. Dzięki tej wiedzy klient nie musi godzić się na wszystko, co jest mu proponowane przez bank. Może sam dokonywać świadomego wyboru, na co może przystać, a z czym się nie zgadza lub co nie jest zgodne z przepisami prawa. Banki wykorzystują niewiedzę swoich klientów. Przedstawiają im, jak twierdzą, jedyne korzystne rozwiązania. Jednak te rozwiązania zazwyczaj są korzystne tylko dla banków. Znajomość podstawowych praw stanowi mechanizm obrony. Dlatego w momencie korzystania z pierwszej usługi oferowanej przez bank, którą jest najczęściej rachunek oszczędnościowy, klient powinien zapoznać się z przysługującymi uprawnieniami. Nikt nie obroni konsumenta skuteczniej niż on sam. 


\title{
BIBLIOGRAFIA
}

Iwanicz-Drozdowska M., 2000, Determinanty bezpieczeństwa banków w świetle analizy wybranych kryzysów bankowych, SGH, Warszawa.

Kidyba A., 2017, Prawo handlowe, wydanie 19, Wydawnictwo C.H. Beck, Warszawa.

Konstytucja Rzeczypospolitej Polskiej z dnia 2 kwietnia 1997 r., Dz.U. 1997, nr 78, poz. 483.

Pietrzak B., Polański Z., Woźniak B., 2008, System Finansowy w Polsce, Wydawnictwo Naukowe PWN, Warszawa.

Raport dla Urzędu Ochrony Konkurencji i Konsumentów „Konsument na rynku ustug bankowych", Warszawa, lipiec 2009.

Rutkowska-Tomaszewska E., 2013, Ochron prawna klienta na rynku ustug bankowych, Wolters Kluwers, Warszawa.

Sokołowski T., Kidyba A., 2012, Kodeks cywilny, komentarz lex-, Wolters Kluwer Polska, Warszawa.

Ustawa z dnia 23 kwietnia 1964 r. - Kodeks cywilny, Dz.U. 1964, nr 16, poz. 93

Ustawa z dnia 29 sierpnia 1997 r. - Prawo bankowe, Dz.U. 1997, nr 140, poz. 939.

Ustawa z dnia 12 września 2002 r. o elektronicznych instrumentach płatniczych, Dz.U. 2002, nr 169 , poz. 1385 .

Ustawa z dnia 12 maja 2011 r. o kredycie konsumenckim, Dz.U. 2011, nr 126, poz. 715.

Ustawa z dnia 30 maja 2014 r. o prawach konsumenta, Dz.U. 2014, poz. 827.

Ustawa z dnia 10 czerwca 2016 r. o Bankowym Funduszu Gwarancyjnym, systemie gwarantowania depozytów oraz przymusowej restrukturyzacji.

Wyrok Sądu Ochrony Konkurencji i Konsumentów z dnia 30 stycznia 2006 r.

[www1] https://www.nbportal.pl/slownik/pozycje-slownika/system-bankowy [09.04.2018].

\section{KNOWLEDGE OF RIGHTS AND OBLIGATIONS - AS ONE OF THE METHODS OF CONSUMER PROTECTION IN THE BANKING SERVICES MARKET}

\begin{abstract}
The purpose of this article is to indicate the rights and obligations that the consumer has on the banking services market, what he can demand from the bank and what he does not have to agree on. If the consumer knows what entitlements are guaranteed to him by virtue of the law in force he can raise it in contact with the bank. However, rarely anyone knows what is included in laws or regulations, because not everyone knows the law. Latin bonus derived from Roman law Ignorantia iuris nocet (ignorance of the law harms), clearly reflects the position of consumers both on the market of banking services and throughout the entire economy. The thesis of this article is the idea that knowledge of rights and obligations can be one of the effective defense mechanisms of the consumer in the banking services market. I will base my article on research carried out on the knowledge of customer rights in the banking services market.
\end{abstract}

Keywords: Bank Guarantee Fund, bank, bank account, loan, banking services. 